\title{
GLUED LAMINATED TIMBER OF PARICÁ REINFORCED WITH SYNTHETIC FIBERS
}

\author{
Talitha Oliveira Rosa ${ }^{1 *}$, Rodrigo Figueiredo Terezo ${ }^{2}$, Nilson Tadeu Mascia ${ }^{3}$, João Laryan Borges Righez ${ }^{2}$ \\ ${ }^{1 *}$ Federal University of Paraná, Department of Forestry Engineering, Curitiba, Paraná, Brazil - rosa.talitha@ gmail.com* \\ ${ }^{2}$ Santa Catarina State University, Department of Forestry Engineering, Lages, Santa Catarina, Brazil - rodrigo.terezo@udesc.br, \\ joaolaryanbr@gmail.com \\ ${ }^{3}$ State University of Campinas, Department of Civil Engineering, Campinas, São Paulo, Brazil - nilson@fec.unicamp.br
}

Recebido para publicação: 25/04/2018 - Aceito para publicação: 23/08/2018

\begin{abstract}
Resumo
Madeira laminada colada de paricá reforçada com fibras sintéticas. O objetivo foi avaliar o desempenho de madeiras laminada (MLC) de Schizolobium parahyba var. amazonicum (paricá) reforçadas com fibras de vidro ou carbono coladas com adesivo resorcinol através de ensaios de flexão estática, cisalhamento e tração paralela e perpendicular às fibras e linha de colagem e comparar os resultados experimentais com os analíticos. Os ensaios de flexão foram divididos em 5 Tratamentos (T) compostos por 6 corpos de prova, sendo $\mathrm{T} 1$ o controle sem reforço de fibras, T2 com fibra de vidro de $110 \mathrm{~g} \cdot \mathrm{m}^{-2}$ de gramatura, T3 com fibra de vidro de $200 \mathrm{~g} \cdot \mathrm{m}^{-2}$, T4 fibra de vidro de $330 \mathrm{~g} \cdot \mathrm{m}^{-2}$ e T5 com reforço de fibra de carbono de $200 \mathrm{~g} \cdot \mathrm{m}^{-2}$. O Módulo de Elasticidade Longitudinal - Ew dos ensaios de flexão foi estimado por cálculos analítico e experimental. Os resultados foram analisados pelo teste de Tukey com 5\% de significância. Não houve um aumento significativo no valor do $\mathrm{E}_{\mathrm{W}}$ e na resistência à flexão, na resistência à tração paralela, perpendicular ou cisalhamento na linha de colagem para todos os tratamentos. O cálculo analítico resultou num deslocamento significativamente menor do que o experimental. $\mathrm{O}$ adesivo resorcinol teve desempenho satisfatório à flexão, sem rupturas por tração ou cisalhamento.

Palavras-chave: Resistência à Flexão; Deslocamento teórico; Deslocamento Experimental.
\end{abstract}

\begin{abstract}
The aim was to evaluate the performance of laminated timber (GLULAM) of Schizolobium parahyba var. amazonicum (paricá) reinforced with fiber of glass or carbon glued with resorcinol adhesive through static bending, shear and tension parallel and perpendicular to the grain and glued line tests and compare the experimental results with analytical ones. The bending test was divided in 5 treatments (T) composed by 6 test specimens, being T1 the control without fiber reinforcement, T2 with fiberglass of $110 \mathrm{~g} \cdot \mathrm{m}^{-2}$ from grammage, T3 with fiberglass of $200 \mathrm{~g} \cdot \mathrm{m}^{-2}$, T4 with fiberglass of $330 \mathrm{~g} \cdot \mathrm{m}^{-2}$; and T5 with carbon fiber of $200 \mathrm{~g} \cdot \mathrm{m}^{-2}$. The Longitudinal Modulus of Elasticity - MOE of bending test was obtained by analytical and experimental designs. The results were analyzed by Tukey's test with $5 \%$ of significance. There were not a significant increase of the MOE value and the bending strength, of tensile or shear strength in the glued line for all treatments. The analytical design results in displacements significant lower than the experimental. The resorcinol adhesive had a satisfactorily bending performance without ruptures by tension parallel and perpendicular to the grain or shear.

Keywords: Bending strength; Theorical displacement; Experimental displacement.
\end{abstract}

\section{INTRODUCTION}

Glued Laminated Timber (GLULAM) is a product made by laminated timbers glued one over the other and its using is applicable in several types of construction. The brazilian production of GLULAM uses mostly Pinus and Eucalyptus wood species. The researches with these two species are more profound and discussed. However, the GLULAM of paricá wood is gaining prominence at the scientific areas.

Paricá wood species (Schizolobium parahyba var. amazonicum (Huber ex Ducke) Barneby) presents compatible values to the GLULAM production (ALMEIDA et al., 2013; TEREZO et al., 2015; AJDINAJ; HABIPI, 2015). Its density varies between $250 \mathrm{~kg} \cdot \mathrm{m}^{-3}$ to $510 \mathrm{~kg} \cdot \mathrm{m}^{-3}$. Studies evaluated the properties of paricá for structural usage and obtained positive results with GLULAM beams with different types of adhesives (TEREZO; SZÜCS, 2010; ALMEIDA et al., 2013; TEREZO et al., 2015).

Although Paricá GLULAM is significantly better than sawn timber (TEREZO; SZÜCS, 2010), the ultimate displacement in GLULAM element remains higher than in the other materials such as concrete (GLIŠOVIĆ et al., 2015a). The presence of timber defects, caused by natural variations, can impair the final

FLORESTA, Curitiba, PR, v. 49, n. 3, p. 459 - 468, jul/set 2019.

Rosa, T. O. et.al.

ISSN eletrônico 1982-4688

DOI: $10.5380 /$ rf.v49 i3.59114 
performance of a structural element as GLULAM (KLIGER et al., 2015). Nevertheless, the reinforcements applied on the GLULAM element can minimize this fragility, increasing its strength capacity (KHELIFA et al., 2015).

The use of synthetic fibers reinforcements, such as aramid fiber (QING; JIAN, 2011), glass fiber (ALHAYED; SVECOVA, 2012; RAFTERY; WHELAN, 2014), carbon fiber (JESUS et al., 2012) and natural fiber as sisal (MASCIA et al., 2014), increase resistance and the Modulus of Elasticity (MOE). The MOE is an important parameter for both performance analysis and the classification of the laminates timber.

The MOE of each laminated timber provides their positioning in the assembly of GLULAM beams. The knowledge of the MOE, for laminated timber and fiber reinforcement, affords to estimate the final compatible MOE and its total deformation to the whole GLULAM element. The Homogenization Method Section (HMS) for GLULAM beams consists in estimating analytically the final compatible MOE by mathematical expressions (BODIG; JAYNE, 1993). The estimation of MOE by this method decreases the use of destructive laboratory tests. This methodology has applicability in the GLULAM industry, ensuring the rational use of laminated timbers and homogenizing the final performance of GLULAM elements.

Researches over reinforcements uses the Epoxy resin as an adhesive (JESUS et al., 2012; ROSA GARCÍA et al., 2013; ANDRÉ et al., 2013; GLIŠOVIĆ et al., 2015a; GLIŠOVIĆ et al., 2015b). Thus, it is important to evaluate the performance of these reinforcements with others structural adhesives (NADIR et al., 2016) already used by Brazilian industry (resorcinol, urea-formaldehyde, polyurethane, among others). Therefore, the aim of this study was to evaluate the performance of paricá GLULAM reinforced with glass or carbon fiber applied with resorcinol-based adhesive. The using of the model to evaluate the shear strength on the glued line based on the French Standard (ANF B 5-32, 1942), and comparing the experimental results with the analytical ones obtained by the Homogenization Method Section - HMS.

\section{MATERIALS AND METHODS}

\section{Sampling and determination of moisture content and density}

Paricá timber used in this research was from planted forests of Amazon in northeast region of Pará State (PA). The randomly selected trees were 6,10,19 and 28 years old. The trees used in this study were $12 ; 3$ for each age. The trees were sectioned in $4 \operatorname{logs}$ with $2,5 \mathrm{~m}$ of length. The first and second ages were planted in the city of Aurora do Pará (latitude $2^{\circ} 10^{\prime} 27,5^{\prime \prime} \mathrm{S}$ and longitude $47^{\circ} 32^{\prime} 42,0^{\prime \prime} \mathrm{W}$ ) and the other ages were planted in the city of Tomé-Açu (latitude $2^{\circ} 23^{\prime} 42,7^{\prime \prime} \mathrm{S}$ e longitude $48^{\circ} 08^{\prime} 43,4^{\prime \prime} \mathrm{W}$ ).

The logs were sawn on boards of $250 \mathrm{~cm} \times 20 \mathrm{~cm} \times 5 \mathrm{~cm}$. After they kiln-dried at $12 \%$ moisture in the capital Belém (PA) and were transported to the Wood Technology Laboratory in the Municipality of Lages-SC. The boards remained stored and protected from inclement weather until they reach equilibrium moisture and were sawn in 120 laminated with $241 \mathrm{~cm} \times 5 \mathrm{~cm} \times 2 \mathrm{~cm}$ with a circular saw.

The moisture content tests and the determination of the paricá's density timber sample were made according to Brazilian Standard ABNT NBR 7190:1997, using 20 test specimens (TS) for each test.

The mechanical characterization of the paricá lot used in this study was made in a previous research (Terezo et al., 2015). The mean values to tensile parallel and perpendicular to the grain, shear strength, compression parallel to the grain and bending are in the Table 1. The same research observed that the paricá does not have a normal distribution of mechanical properties over the age and its classification is C-20 to its use as as structural timber. Therefore, to homogenize the boards used in this study, a nondestructive test was made to obtain the stiffness.

Table 1. Mechanical properties to paricá wood in different ages.

Tabela 1. Propriedades mecânicas da madeira de paricá em diferentes idades.

\begin{tabular}{ccccccccc}
\hline $\begin{array}{c}\text { Mechanical } \\
\text { Properties }\end{array}$ & \multicolumn{2}{c}{ 6 years } & \multicolumn{2}{c}{ 10 years } & \multicolumn{2}{c}{ 19 years } & \multicolumn{2}{c}{ 28 years } \\
\cline { 2 - 9 } & $\begin{array}{c}\text { Strength } \\
(\mathbf{M P a})\end{array}$ & $\mathbf{M O E}$ & $\begin{array}{c}\text { Strength } \\
\text { MOE }\end{array}$ & $\begin{array}{c}\text { Strength } \\
(\mathbf{M P a})\end{array}$ & $\begin{array}{c}\text { MOE } \\
\text { (MPa) }\end{array}$ & $\begin{array}{c}\text { Strength } \\
\text { (MPa) }\end{array}$ \\
\hline Tensile parallel & 80.83 & 63.52 & 46.73 & & 54.94 & \\
\hline $\begin{array}{c}\text { Tensile } \\
\text { perpendicular }\end{array}$ & 3.23 & & 2.86 & & 2.68 & & 2.56 & \\
\hline $\begin{array}{c}\text { Shear } \\
\text { Compression } \\
\text { parallel }\end{array}$ & 2.72 & & 2.62 & & 2.35 & & 2.99 & \\
\hline Bending & 30.84 & 11418 & 30.03 & 10479 & 26.96 & 11751 & 29.46 & 10582 \\
\hline & 57.50 & 9293 & 61.11 & 9332 & 44.63 & 8190 & 45.88 & 8137 \\
\hline
\end{tabular}




\section{Preparation of specimens to GLULAM Test}

The boards in this study have been evaluated by the visual classification in accordance to the ABNT NBR 7190:1997, to avoid any presence of knots or other defects.

The laminated were systematically distributed according to the MOE obtained by the three-point bending nondestructive test, as followed by the American Standard D4761 (ASTM, 2002). The MOE of each laminated timber were grouped from highest to lowest value. In other to produce uniformes GLULAM TSs, the laminated timber with the higher MOE was positioned on the outer edge in the area with maximum tensile stress and the second laminated with higher MOE was positioned on the outer edge area of maximum compression stress. The laminated timber with lower MOE were positioned in the central region of GLULAM TS. This systemathic distribution occurred successively, until GLULAM TS was composed by four laminated timbers.

The laminated timbers were flattened with $1.2 \mathrm{~cm}$ of thickness and cleaned with a compressed air jet. The adhesive used was RS $215 \mathrm{M}$ (resorcinol), from Momentive ${ }^{\circledR}$, the grammage was $300 \mathrm{~g} \cdot \mathrm{m}^{-3}$ plus 20 parts of hardener.

At the highest tension area of the beams, in the lower part of specimen, the synthetic fibers were positioned, in tissue form. For the tissues fixation, on the last laminate timber of the GLULAM TS, the adhesive was applied followed by the fabric positioning. The fabrics were deaerated to eliminate possible air bubbles and to increase the adherence among synthetic fiber/adhesive/timber. At the end, above the synthetic fiber a new layer of adhesive was applied and the deaeration process was carried out again.

The GLULAMS TS had been cold-pressed for 24 hours, with bonding pressure between $0.7 \mathrm{MPa}$ and 1.4 $\mathrm{MPa}$. Afterward, they took them to the climatization room where they remain for 7 days to conclude the bonding. After this period, the GLULAMS TS flattened and top cut had the final dimensions of $115 \mathrm{~cm} \times 4.5 \mathrm{~cm} \times 4.8 \mathrm{~cm}$.

According to the product datasheet, the thickness of fibers used at this work, its percentage in relation to transversal section and its MOE are in the Table 2.

Table 2. Thickness, percentage and MOE of glass fibers and carbon fiber with different grammages.

Tabela 2. Espessura, percentagem e módulo de elasticidade das fibras de vidro e fibras de carbono com diferentes gramaturas.

\begin{tabular}{cccc}
\hline Fiber $\left(\mathbf{g}^{-2}\right)$ & $\begin{array}{c}\text { Final thickness } \\
\text { with adhesive }(\mathbf{m m})\end{array}$ & Percentage & MOE (MPa) \\
\hline Glass 110 & 1.15 & 2.40 & 32.784 \\
\hline Glass 200 & 1.18 & 2.46 & 59.697 \\
\hline Glass 330 & 1.30 & 2.70 & 98.352 \\
\hline Carbon 200 & 1.40 & 2.92 & 182.857 \\
\hline
\end{tabular}

\section{Production of specimens to parallel and perpendicular tensile and shear to the grain}

The tensile parallel to the grain TS had extracted from solid timber according to ABNT NBR 7190:1997. The synthetic fiber fabrics were cutted with lengths of $10 \mathrm{~cm}$ and glued on both sides of the specimens at the central region of the solid timber.

The shear and the tensile perpendicular specimens had extracted from 4 others GLULAM TS with synthetic fibers reinforcement in the central line. The perpendicular tension specimens were made according to the ABNT NBR 7190:1997. The shear TS were adapted from French Standart (ANF B 5-32, 1942). The dimensions of specimen were more appropriate for this work, since in the central region of the shear and perpendicular TS is positioned the reinforcing fiber. In this way, the rupture occurs due to the pure shear, in the region of the most fragile reinforcement, area A or B of the glue line, since the system of forces acts on the longitudinal axis (Figure 1). The use of this test sample also provides lower coefficient of variation than the $28 \%$ required by the ABNT NBR 7190:1997 as showed by Terezo et al., 2015.

FLORESTA, Curitiba, PR, v. 49, n. 3, p. 459 - 468, jul/set 2019.

Rosa, T. O. et.al.

ISSN eletrônico 1982-4688 


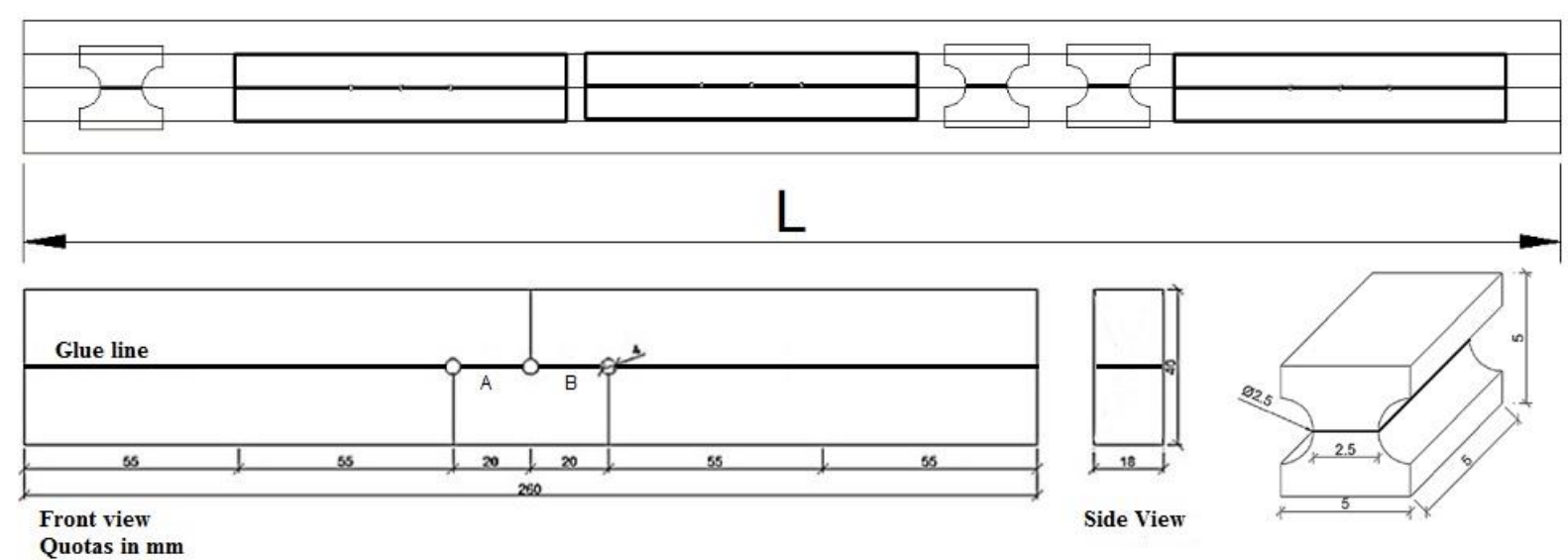

Figure 1. Scheme of the extraction of specimens from GLULAM beams and illustration of the specimen of shear strength adapted from French Standard AFN B 5-32 and the specimen of tensile perpendicular to the grain from ABNT NBR 7190:1997.

Figura 1. Esquema da extração dos corpos de prova de vigas de MLC e ilustração dos corpos de prova de cisalhamento adaptado da norma francesa AFN B 5-32 e o corpo de prova da tração normal às fibras da ABNT NBR 7190:1997.

\section{Bending test}

The bending test followed the recommendations of ABNT NBR 7190:1997. The GLULAMS TS were bi-supported in the flatwise position, in other words, the GLULAM were in the horizontal position. An inductive transducer (linear variable differential transducer - LVDT) mensured the displacement of the beams. At the symmetry point and at the height of the GLULAM TS's neutral line (L.N), it was positioned the inductive transducer as shown in Figure 2.
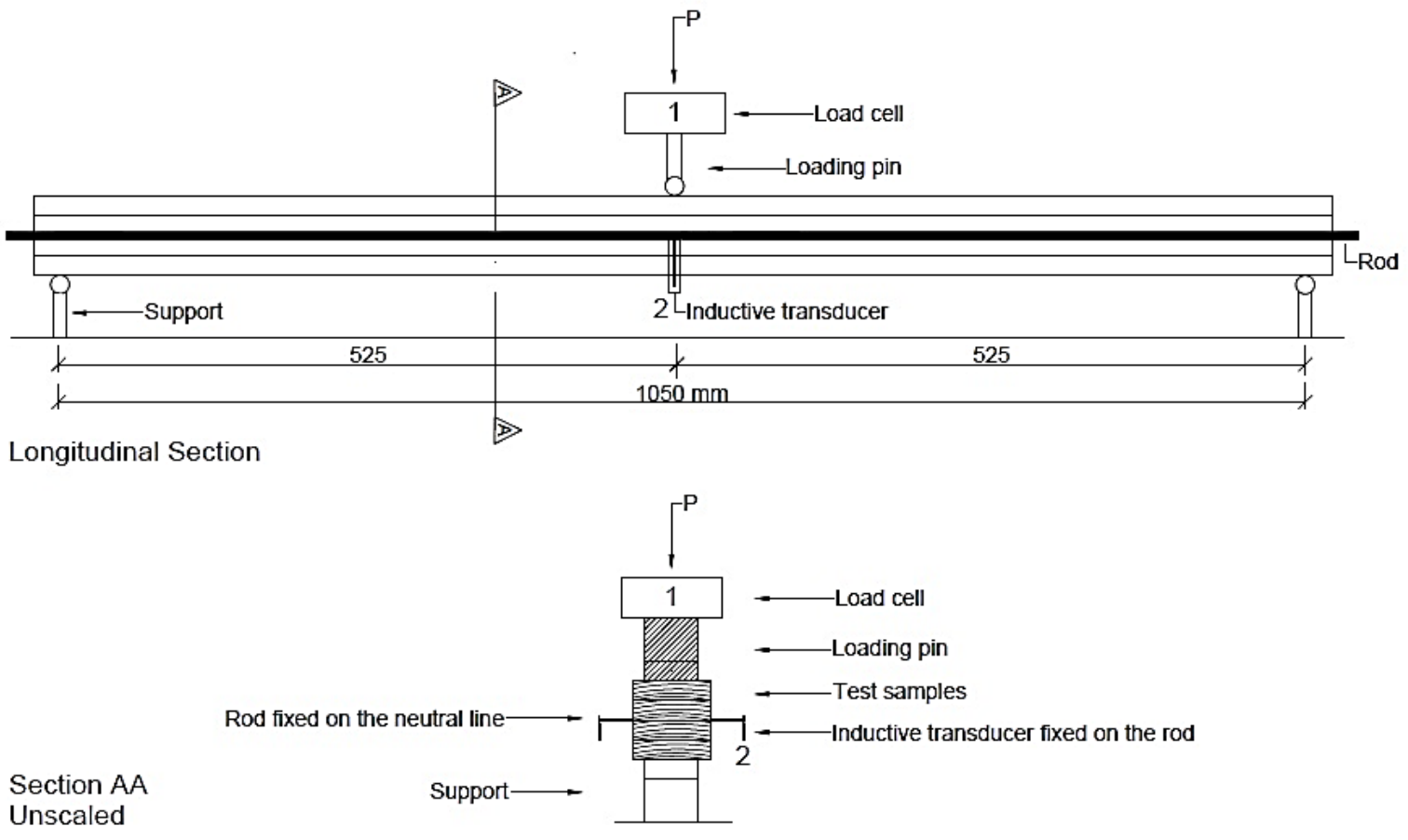

Figure 2. Three-point bending test scheme, where (1) is the load cell, (2) the displacement transducer positioned at the neutral line (dimensions in $\mathrm{mm}$ ).

Figura 2. Esquema do teste de flexão à três pontos, onde (1) é a célula de carga, (2) o transdutor de deslocamento posicionado na linha neutra (dimensões em mm). 


\section{Compatible modulus of elasticity by HMS}

The following mathematical expressions were used for the Homogenization Method Section (HMS) applied in this work to compatibilize the MOE of the GLULAM TS and to estimate the total displacement on bending:

$\left.1^{\circ}\right)$ Definition of laminated timber width of the transformed section, choosing as width, the lower MOE laminated timber (Equation 1):

$$
\mathrm{b}^{*}=\mathrm{b} \cdot \frac{\mathrm{E}_{\mathrm{i}}}{\mathrm{E}_{\mathrm{c}}}
$$

Where: $\mathrm{b}^{*}=$ new width to laminated timber $(\mathrm{cm}) ; \mathrm{b}=$ chosen laminated timber width $(\mathrm{cm}) ; \mathrm{E}_{\mathrm{i}}=$ MOE of the laminated timber $(\mathrm{MPa}) ; \mathrm{e} \mathrm{E}_{\mathrm{c}}=\mathrm{MOE}$ of the chosen laminated timber (MPa).

$2^{\circ}$ ) Determination of new area to the laminated timber and to GLULAM TS (Equation 2):

$\mathrm{A}^{*}=\mathrm{b}_{\mathrm{i}}{ }^{*} \cdot \mathrm{t}$

Where: $\mathrm{A}^{*}=$ new area to the laminated timber $\left(\mathrm{cm}^{2}\right) ; \mathrm{b}_{\mathrm{i}}{ }^{*}=$ new width of the laminated timber determinate $(\mathrm{cm}) ; \mathrm{e} t=$ thickness of the laminated timber $(\mathrm{cm})$.

$3^{\circ}$ ) Due to the altered geometry of the TS, a redefinition of the centroid of the transformed section throughout which the neutral lines pass by was needed (Equation 3):

$$
\mathrm{y}_{\ln }=\frac{\sum_{\mathrm{i}=1}^{\mathrm{n}} \mathrm{A}_{\mathrm{i}}^{*} \cdot d \mathrm{di}}{\sum_{\mathrm{i}=1}^{\mathrm{n}} \mathrm{A}_{\mathrm{i}}^{*}}
$$

Where: $\mathrm{di}=$ distance between the center of the laminated timber and an arbitrary horizontal axis; and $\mathrm{y}_{\mathrm{ln}}$ $=$ the distance between the section centroid and the arbitrary axis.

$4^{\circ}$ ) Definition of the moment of inertia to the bending of a composite area (Equation 4):

$\mathrm{I}^{*}=\mathrm{I}+\mathrm{A}^{*} \cdot \mathrm{d}^{2}$

Where: $I^{*}=$ moment of inertia of a composed area $\left(\mathrm{cm}^{4}\right) ; \mathrm{I}=$ moment of inertia of each laminated timber $\left(\mathrm{cm}^{4}\right) ; \mathrm{A}^{*}=$ new area of laminated timber $\left(\mathrm{cm}^{2}\right)$; e d $=$ distance between the neutral line of GLULAM and the neutral line of laminated timber.

$\left.5^{\circ}\right)$ Definition of the static moment of area (Equation 5):

$\mathrm{Q}^{*}=\sum \mathrm{A}_{\mathrm{i}}{ }^{*} \cdot \mathrm{yi}$

Where: $\mathrm{Q}^{*}=$ static moment of area $\left(\mathrm{cm}^{3}\right)$; e yi= distance between the laminated timber center and the gravity center of the GLULAM $(\mathrm{cm})$.

$6^{\circ}$ ) Definition of the form factor $\left(\chi^{*}\right)$ to the new GLULAM (Equation 6):

$\chi^{*}=\frac{A^{*}}{\left(I^{*}\right)^{2}} \sum_{i=1}^{n} \frac{1}{b_{i}^{*}} \int\left(Q^{*}\right)^{2} d y$

Simpson's Rule was adopted to evaluate the integral contained in the Equation 7:

$\int_{\text {laminated }}\left(\mathrm{Q}^{*}\right)^{2} \mathrm{dy}=\frac{\mathrm{t}}{6}\left[\mathrm{Q}^{* 2}\left(\mathrm{y}_{\mathrm{s}}\right)+4 \mathrm{Q}^{* 2}\left(\mathrm{y}_{\mathrm{c}}\right)+\mathrm{Q}^{* 2}(\mathrm{i})\right]$

Where: $y_{s}, y_{c}$ e $y_{i}$ are, respectively, coordinates y superior, central and inferior of the laminated timber.

$7^{\circ}$ ) Definition of the transversal modulus of elasticity by ABNT NBR 7190:1997, (Equation 8):

$\mathrm{G}_{\mathrm{c}}=\frac{\mathrm{E}_{\mathrm{c}}}{20}$

Where: $\mathrm{G}_{\mathrm{c}}=$ transversal modulus of elasticity (shear); and $\mathrm{E}_{\mathrm{c}}=$ modulus of elasticity obtained by compression test of the chosen laminated timber (MPa). It was assumed in this work that $\mathrm{E}_{\mathrm{c}}$ is equal to MOE.

$8^{\circ}$ ) Calculation of maximum displacement (Equation 9):

$\mathrm{v}=\frac{\mathrm{P} \cdot \mathrm{a}}{48 \cdot \mathrm{E}_{\mathrm{C}} \cdot \mathrm{I}^{*}}\left(3 \mathrm{I}^{2}-4 \mathrm{a}\right)+\frac{\mathrm{P} \cdot \mathrm{a} \cdot \chi^{*}}{2 \cdot \mathrm{G}_{\mathrm{c}} \cdot \mathrm{A}^{*}}$

Where: $\mathrm{v}=$ maximum displacement $(\mathrm{cm})$; e $\mathrm{P}=$ estimated maximum load $(\mathrm{kN})$

FLORESTA, Curitiba, PR, v. 49, n. 3, p. 459 - 468, jul/set 2019.

Rosa, T. O. et.al.

ISSN eletrônico 1982-4688 


\section{Statistical treatment}

The experimental design composition by treatment was 6 GLULAM TS to bending test and 12 TS for each test of strength to the glued line. The treatments were T1 (control without fiber reinforcement), T2 (glass fiber $-110 \mathrm{~g} \cdot \mathrm{m}^{-2}$ ), T3 (glass fiber $-200 \mathrm{~g} \cdot \mathrm{m}^{-2}$ ), T4 (glass fiber $-330 \mathrm{~g} \cdot \mathrm{m}^{-2}$ ), T5 (carbon fiber $-200 \mathrm{~g} \cdot \mathrm{m}^{-2}$ ). The statistical evaluation among treatments and the evaluation between experimental and analytical results were according to the the mean values. The statistical analysis were completely randomized design and Tukey's test to compare the averages among treatments.

\section{RESULTS}

The average moisture content of the paricá timber was $13.87 \%$. The basic and bulk density were 340 $\mathrm{kg} \cdot \mathrm{m}^{-3}$ e $410 \mathrm{~kg} \cdot \mathrm{m}^{-3}$, respectively.

The use of resorcinol-based adhesive presented higher results for all treatments with glass fiber reinforcements than the carbon fiber (Table 3). When comparing the reinforced treatments with $\mathrm{T} 1$, the greatest increases in characteristic strength were for T4 (axial 17.57\%, shear of 4.32\%), followed by T2 (axial 14.32\%, shear of 1.44\%) and T3 (axial 2.87\%). However, the treatments T3 and T5 had presented a decrease in shear strength. Despite the increases and decreases in values among the evaluated properties, the mean test reveals that there were no significant differences between the treatments.

Table 3. Mean and characteristics values of the GLULAM TS obtained from the bending test by treatment.

Tabela 3. Valores médios e característicos por tratamento dos corpos de prova de MLC obtidos pelo teste de flexão.

\begin{tabular}{|c|c|c|c|c|}
\hline \multirow{2}{*}{ Treatments } & & \multicolumn{2}{|c|}{ Bending Strenght (MPa) } & \multirow{2}{*}{$\begin{array}{l}\text { MOE } \\
\text { (MPa) }\end{array}$} \\
\hline & & Axial & Shear & \\
\hline \multirow{3}{*}{ T1 } & Mean & $57.99 \mathbf{a}$ & $1.44 \mathbf{a}$ & $11455 \mathbf{a}$ \\
\hline & C.V $(\%)$ & 13.37 & 13.55 & 9.40 \\
\hline & $\mathrm{f}_{\mathrm{k}, 12 \%}$ & 51.96 & 1.39 & \\
\hline \multirow{4}{*}{$\mathbf{T 2}$} & Mean & $62.26 \mathbf{a}$ & $1.48 \mathbf{a}$ & $11422 \mathbf{a}$ \\
\hline & C.V $(\%)$ & 21.03 & 21.03 & 11.59 \\
\hline & $\mathrm{f}_{\mathrm{k}, 12 \%}$ & 59.40 & 1.27 & \\
\hline & Increase $(\%)$ & 14.32 & 1.44 & -0.29 \\
\hline \multirow{4}{*}{$\mathbf{T 3}$} & Mean & $58.64 \mathbf{a}$ & $1.40 \mathbf{a}$ & $13321 \mathbf{a}$ \\
\hline & C.V $(\%)$ & 13.66 & 13.66 & 18.24 \\
\hline & $\mathrm{f}_{\mathrm{k}, 12 \%}$ & 53.45 & 1.27 & \\
\hline & Increase $(\%)$ & 2.87 & -8.63 & 16.29 \\
\hline \multirow{4}{*}{$\mathbf{T 4}$} & Mean & $64.55 \mathbf{a}$ & $1.54 \mathbf{a}$ & $12660 \mathbf{a}$ \\
\hline & C.V $(\%)$ & 9.69 & 9.69 & 9.14 \\
\hline & $\mathrm{f}_{\mathrm{k}, 12 \%}$ & 61.09 & 1.45 & \\
\hline & Increase $(\%)$ & 17.57 & 4.32 & 10.52 \\
\hline \multirow{4}{*}{ T5 } & Mean & $59.76 \mathbf{a}$ & $1.42 \mathbf{a}$ & $12142 \mathbf{a}$ \\
\hline & C.V $(\%)$ & 25.53 & 25.53 & 14.93 \\
\hline & $\mathrm{f}_{\mathrm{k}, 12 \%}$ & 52.16 & 1.24 & \\
\hline & Increase $(\%)$ & 0.38 & -10.79 & 6.00 \\
\hline
\end{tabular}

Means followed by same letter at the line have no difference between each other by the test of Tukey at 5\% significance level. C.V - Coefficient of variation $(\%) ; \mathrm{f}_{\mathrm{k}, 12 \%}=$ characteristic strength adjusted to moisture content of $12 \%$.

The mean values for shear strength, tensile perpendicular and parallel to the grain are presente in the Table 4. The coefficient of variation in all treatments, except for the T3, to evaluate the shear had values below the maximum required by the Brazilian Standard ABNT NBR 7190:1997. In the tests of tensile perpendicular to the grain and shear in glue line there were significant differences of values. The treatment T5 (carbon fiber) presented the better results in the tensile perpendicular test the same occured to the shear strength test. Nevertheless, an opposite behavior occurred on the tensile parallel test, resulting with the lower values. The highest characteristic tensile parallel test was in the T2 treatment with $34.02 \mathrm{MPa}$, followed by T4 with $32.40 \mathrm{MPa}$, T3 with $26.40 \mathrm{MPa}$ and T5 with a strength of $25.3 \mathrm{MPa}$.

Comparing the values of shear on the bending test (Table 3 ) with the values of shear of glue line (Table 4) it have been determined which tensions caused the ruptures of the beams. There were no ruptures at the TS caused by shear stresses, once the values of rupture on the beams were below than the values of shear strength of the glue line. 
Table 4. Glue line tensile and shear strengths.

Tabela 4. Resistência à tração e cisalhamento da linha de cola.

\begin{tabular}{|c|c|c|c|c|c|c|}
\hline \multirow{2}{*}{ Properties } & & \multicolumn{5}{|c|}{ Treatments } \\
\hline & & T1 & $\mathbf{T 2}$ & T3 & $\mathbf{T 4}$ & T5 \\
\hline \multirow{3}{*}{$\begin{array}{l}\text { Tension parallel } \\
\text { to the grain }\end{array}$} & Mean & $36.33 \mathbf{a}$ & $44.69 \mathbf{a}$ & $39.15 \mathbf{a}$ & $43.76 \mathbf{a}$ & $36.02 \mathbf{a}$ \\
\hline & C.V (\%) & 30.64 & 28.97 & 35.40 & 21.12 & 28.08 \\
\hline & $\mathrm{f}_{\mathrm{t} 0, \mathrm{k}}(12 \%)$ & 25.81 & 34.02 & 32.37 & 32.40 & 25.73 \\
\hline \multirow{3}{*}{$\begin{array}{c}\text { Tension } \\
\text { Perpendicular to } \\
\text { the grain }\end{array}$} & Mean & $1.87 \mathbf{a b}$ & $1.22 \mathrm{c}$ & 1.64 abc & $1.37 \mathrm{bc}$ & $1.97 \mathbf{a}$ \\
\hline & C.V (\%) & 22.59 & 45.07 & 24.83 & 34.83 & 18.25 \\
\hline & $\mathrm{f}_{\mathrm{t} 90, \mathrm{k}}(12 \%)$ & 1.45 & 0.85 & 1.26 & 0.81 & 1.62 \\
\hline \multirow{3}{*}{ Shear } & Mean & $1.85 \mathbf{a b}$ & $1.53 \mathrm{~b}$ & $1.92 \mathbf{a b}$ & $2.00 \mathbf{a b}$ & $2.07 \mathbf{a}$ \\
\hline & C.V (\%) & 24.05 & 21.64 & 29.45 & 15.54 & 23.77 \\
\hline & $\mathrm{f}_{\mathrm{v} 0, \mathrm{k}}(12 \%)$ & 1.59 & 1.21 & 1.40 & 1.68 & 1.37 \\
\hline
\end{tabular}

Means followed by same letter at the line have no difference between each other by the test of Tukey at $5 \%$ of significance level. C.V Coefficient of variation $(\%) ; \mathrm{f}_{\mathrm{t} 0, \mathrm{k}}-$ Characteristic strength tension parallel to the grain; $\mathrm{f}_{\mathrm{t} 90, \mathrm{k}}-$ Characteristic strength tension perpendicular to the grain; $\mathrm{f}_{\mathrm{v} 0, \mathrm{k}}-$ Characteristic strength to shear in glued line.

At comparing the analytical displacement for $\mathrm{T} 1$, it is noticed a higher value than the observed experimentally, with a relative difference of $2.79 \%$ (Table 5). It demonstrates that the difference predicted by HMS gives a security zone to designs of structures, the same occurred to T2. The statistical tests revealed that at the T1, T2, T3 the HMS predicted the displacement of the GLULAM beams even when reinforced with glass fiber up to $200 \mathrm{~g} \cdot \mathrm{m}^{-2}$ of grammage. Whereas, at the T4 and T5, significant statistics indicated a difference to the prediction of the displacement at GLULAM beams reinforced with glass fiber and carbon fiber, grammage $300 \mathrm{~g} \cdot \mathrm{m}^{-2}$ and 200 $\mathrm{g} \cdot \mathrm{m}^{-2}$, respectively.

Table 5. Analytical and experimental comparison means for displacements and MOE.

Tabela 5. Comparação das médias analíticas e experimentais pelos deslocamentos e $\mathrm{E}_{\mathrm{W}}$.

\begin{tabular}{cccccccc}
\hline & \multicolumn{9}{c}{ Means } & \multicolumn{3}{c}{ MOE } \\
\cline { 2 - 8 } Treatments & $\begin{array}{c}\boldsymbol{\delta} \\
\text { (ana.) } \\
(\mathbf{c m})\end{array}$ & $\begin{array}{c}\boldsymbol{\delta} \\
(\mathbf{e x p}) \\
(\mathbf{c m})\end{array}$ & $\begin{array}{c}\text { Abs } \\
\text { Dif. } \\
(\mathbf{c m})\end{array}$ & $\begin{array}{l}\text { Rel. } \\
\text { Dif. } \\
(\boldsymbol{\%})\end{array}$ & Analytical & Experimental & \\
& 0,92 & 0,90 & $-0,02$ & $-2,79$ & $11.774,14 \mathbf{a}$ & $11.455,29 \mathbf{a}$ & 0.7423 \\
\hline T1 & 0,89 & 0,88 & 0,01 & $-0,12$ & $12.046,91 \mathbf{a}$ & $11.422,13 \mathbf{a}$ & 0.3456 \\
\hline T2 & 0,75 & 0,80 & 0,05 & 3,30 & $13.921,88 \mathbf{a}$ & $13.321,31 \mathbf{a}$ & 0.6215 \\
\hline T3 & 0,68 & 0,83 & 0,15 & 16,95 & $16.194,90 \mathbf{a}$ & $12.660,02 \mathbf{b}$ & 0.0002 \\
\hline T4 & 0,48 & 0,80 & 0,32 & 40,23 & $21.627,66 \mathbf{a}$ & $12.142,64 \mathbf{b}$ & 0.0000 \\
\hline
\end{tabular}

Means followed by same letter at line have no difference between each other by test of Tukey at $5 \%$ significance level. $\delta$ (ana.). $=$ Analytical displacement on $50 \%$ of maximum load. $\delta$ (exp.) = Experimental displacement on $50 \%$ of maximum load. Abs Dif. $=$ absolute difference. Rel.Dif. = Relative difference.

\section{DISCUSSION}

The values of moisture content, basic and bulk density show that the timber of this research was fit to using at GLULAM beams as suggested by Terezo and Szücs (2010) e Ajdinaj and Habipi (2015). The authors described that timber with moisture content between $10 \%$ and $14 \%$ and with a moderate basic density can be used in GLULAM, favoring the glue impregnation.

The using of resorcinol-based adhesive to glue the synthetic fibers indicated an increase of the characteristic axial resistances. At the percentage increments it noticed that the glass fibers provided up to $17,6 \%$ higher values than the characteristical values of the beams without reinforcements. The same behavior has not happened to the carbon fiber, since only $0.38 \%$ of increased occurred to the studied beams.

There is a tendency of increase the resistance of beams with glass fibers than carbon fiber when using resorcinol adhesive. Furthermore, high increases of resistances of carbon fiber was noticed only when using epoxy resin as the results obtained by Nadir et al. (2016) in the bending streght. However, the reinforcement made with two layers of carbon fiber and epoxy resin did not implied an increase in the carrying capacity of the beams (Rosa García et al., 2013). The same tendency occurred in this study to the glass fiber, since there was not increase of resistance when the grammage of fiber was higher.

FLORESTA, Curitiba, PR, v. 49, n. 3, p. 459 - 468, jul/set 2019.

Rosa, T. O. et.al.

ISSN eletrônico 1982-4688 
The low increases were attributed to the higher grammage of synthetic fibers that hindered the adhesive penetration, reducing its adhesion into the timber, consequently resulting in lower values of resistance. However, the decrease in shear strength on T3 and T5 are not observed in the literature when using the epoxy resin (RAFTERY; WHELAN, 2014; GLIŠOVIĆ et al., 2015a; GLIŠOVIĆ et al., 2015b; CHEW et al., 2015). As the ruptures starting in the laminated timbers, it can explain the loss of resistance. Since it is possible to have a higher stress concentration in the reinforced laminated timbers, mainly for carbon fiber reinforcement (T5).

Analyzing only the tensile perpendicular in the glue line, the use of glass fibers with grammage $110 \mathrm{~g} \cdot \mathrm{m}^{-}$ ${ }^{2}$ would not be feasible for reinforcement since the characteristic values were statistically lower than the timber unreinforced. The averages of the tensile perpendicular in the glue line of all treatments were lower than Terezo and Szücs (2010) that using only adult trees achieved 3.47 MPa. However, as paricá does not have a normal distribution of mechanical properties over the age (Terezo et al., 2015) that variable cannot be the reason for differences in the resistance. Therefore, the stress concentration also provided the loss of resistance in perpendicular test, since no rupture occurred in the region of the glue reinforced line. It indicated that even the lower reinforcement of fibers $(2.40 \%)$ does not rupture when submitted to axial forces.

The same tendency occurred with the values of shear, even inferior to Cavalheiro et al. (2016), that yielded 3.4 MPa and Terezo and Szücs (2010) with 2.02 MPa, most of ruptures did not occur on the glue-reinforced line. In three specimens the rupture occurred in the glue line, part of the rupture was in wood and part in the reinforced line. When analyzing the rupture, it was observed that the glue had not penetrate in the timber, thus in this case, only part of the composite had the proper gluing. The specimen model adopted from the French Standard to evaluate the shear presented a good variability of data, even when using reinforced glue line.

The low variability at the parallel tension treatments is due to the rupture being mostly in the timber, remaining the fiber reinforcement intact. Terezo et al. (2015), when evaluating the same species and origin also obtained differences among the averages.

When comparing characteristic shear values in the Table 4 with the shear solicitations in the beams, it was observed that the rupture did not occur due to the shear tensions. Since the values of shear in Table 3 are lower than the shear strengths in the Table 4, the beams ruptured by axial tensions. These rupture modes were observed during the bending tests and in the rupture of the beams, meaning that the composite presented good gluing. It also observed that the ruptures on the unreinforced beams had a bigger extension then the beams with reinforcements.

Visually, it was noticed that the rupture of GLULAM reinforced TS had the first fissure in the laminated timber of the tension region. The synthetic fiber/adhesive/timber composite only ruptured after the laminated timber collapse occurred. Khelifa et al. (2015) and Nadir et al. (2016) observed the same behavior, the rupture in reinforced beams occurs by tension, which begins in the wood in the tension area and immediately is followed by the rupture of the reinforcement, only when it reaches its final deformation. The displacements did not increase in the reinforced beams when comparing to the unreinforced beams. The small increase of MOE in the T3, T4 and T5 treatment presented the same behavior as the study of Rosa García et al. (2013). Indicating a good performance of fibers, since even with a higher capacity of load the ultimate displacement maintaining is the same.

The differences at the analytical MOE obtained by HMS and the experimental values (Table 5) implicates that it occured due to the high MOE of fibers. As carbon fiber and glass fiber $-330 \mathrm{~g} \cdot \mathrm{m}^{-2}$ have a higher MOE when comparing to the laminated timbers. Since the method considers the stiffness of the material applied in relation to the stiffness of the laminated timbers, it estimates a high stiffness (MIOTO; DIAS, 2015). The displacement high differences were considered a normal result for Mascia et al. (2014), since the HMS can present differences when comparing to experimental values. Nadir et al. (2016) compared the HMS with experimental values and concluded that differences can occur among the specimens once the method considers the glulam reinforced beam as a solid beam and the lower MOE on experimental results are due to the laminating effects in glued laminated timber beams.

\section{CONCLUSION}

- $\quad$ Based on the work developed, it was concluded that even without statistical significances of tensile strength and shear in bending, a tendency of increase in the axial strength occurred when using glass fiber glued with resorcinol adhesive, the same behavior did not occur to carbon fiber.

- The results obtained with all of the fibers with grammage superior to $200 \mathrm{~g} \cdot \mathrm{m}^{-2}$ increase the stiffness of the beams. The use of the resorcinol adhesive for the gluing synthetic fibers had satisfactory bending performance without presenting ruptures occasioned by tension or shear.

- The model for the specimen to evaluate the shear tensile presented good variability to be used with reinforced glue lines.

- The analytical calculation by HMS estimates a lower displacement than the experimental displacement. 
- More studies are suggested to evaluate the number of layers' fibers and its relationship with the thickness and density of laminated timbers, to this species or to others with potential use to GLULAM. It is also necessary to research on different adhesive grammage and stress concentration modeling in the region of fiber-timber interaction.

\section{ACKNOWLEDGEMENTS}

To CAPES and FAPESC for the financial contribution. To Mr. João de Deus Neto (in memoriam) and Tramontina S/A for the donation of the material of this research.

\section{REFERENCES}

AJDINAJ, D.; HABIPI, B. Wood finger-joint strength as function of finger length and slope positioning of tips. International Journal of Engineering and Applied Sciences (IJEAS), v. 2, n. 12, p. 128 - 132, 2015.

ALMEIDA, D. H.; SCALIANTE, R.M.; MACEDO, L.B.; MACÊDO, A.N.; DIAS, A.A.; CHRISTOFORO, A.L.; CALIL JÚNIOR, C. Caracterização completa da madeira da espécie amazônica paricá (Schizolobium amazonicum HERB) em peças de dimensões estruturais. Árvore, v. 37, n. 6, p. 1175 - 1181, 2013.

ALHAYED, H.; SVECOVA, D. Flexural stiffness and strength of GFRP-reinforced timber beams. Journal of composites for construction, v.16, n. 3, p. 245 - 252, 2012.

AMERICAN SOCIETY FOR TESTING AND MATERIALS - ASTM D4761: mechanical properties of lumber and wood-base structural material. Philadelphia: ASTM, 2002.

ANDRÉ, A.; KLIGER. R.; OLSOON, R. Compression failure mechanism in small-scale wood specimens reinforced with CFRP: an experimental study. Construction and Building materials, v. 41, p. 790 - 800, 2013.

ASSOCIAÇÃO BRASILEIRA DE NORMAS TÉCNICAS. NBR 7190: Projeto de estruturas de madeira. Rio de Janeiro, 1997.

ASSOCIATION FRANCAISE DE NORMALISATION - NF B 5-32: Essai de cisaillement. Paris: AFN, 1942.

BODIG, J.; JAYNE, B.A. Mechanics of wood and wood composites. Van Nostrand, 1982.736 p.

CAVALHEIRO, R.S.; CALIL NETO, C.; CHRISTODORO, A.L.; CALIL JUNIOR, C.; LAHR, F.A.R. Evaluation of shear strength and cyclic delamination of paricá (schizolobium amazonicum) glued laminated timber. Internacional Journal of Materials Engineering, v. 6, p. 60 - 65, 2016.

CHEW, A.A.; RAHIM, N.S.A.; FATIN, N.H.; YASIM, M.; HASSAN, R. Compression strength of composite glulam timber reinforced between first and second, thrid and fourth lamina. Jurnal Teknologi, v. 78, n. 5-4, p. 49 $-55,2016$.

D'AMBRISI, A.; FOCACCI, F.; LUCIANO, R. Experimental investigation on flexural behavior of timber beams repaired with CFRP plates. Composite Structures, v. 108, p. 720 - 728, 2014.

GENTRY, T.R. Performance of glued-laminated timbers with FRP shear and flexural reinforcement. Journal of composites for construction, v.15, p. 861 - 870, 2011.

GLIŠOVIĆ, I.; STEVANOVIĆ, B.; PETROVIĆ, M. Bending behaviour of glulam beams reinforced. Journal of civil engineering and management, v. 21. n.7, p. 923 - 932, 2015a.

GLIŠOVIĆ, I.; STEVANOVIĆ, B.; TODOROVIĆ, M. Flexural reinforcement of glulam beams with cfrp plates. Materials and Structures, v. 49, n. 7, p. 2841 - 2855, 2015 b.

JESUS, A.M.P.; PINTO, J.M.T.; MORAIS, J.J.L. Analysis of solid wood beams strengthened with CFRP laminates of distinct lengths. Construction and Building Materials, v. 35, p. 817 - 828, 2012.

KHELIFA, M.; AUCHET, S.; MÉAUSOONE, P.J.; CELZARD, A. Finite element analysis of flexural strengthening of timber beams with carbono fibre-reinforced polymers. Engineering Structures, v. 101, p. 364 $375,2015$.

FLORESTA, Curitiba, PR, v. 49, n. 3, p. 459 - 468, jul/set 2019.

Rosa, T. O. et.al.

ISSN eletrônico 1982-4688 
KLIGER, I.R.; HAGHANI, R.; BRUNNER, M.; HARTE, A.M.; SCHOBER, K. Wood-based beams strengthened with FRP laminates: improved performance with pre-stressed systems. European Journal of Wood and Wood Produts, v. 74, n. 3, p. 319 - 330, 2015.

MASCIA, N.T.; MAYER, R.M.; MORAES, R.W. Analysis of wood laminated beams reinforced with sisal fibres. Key Engineering Materials, v. 600, p. 97 - 104, 2014.

MIOTO, J.L.; DIAS, A.A. Structural efficiency of full-scale timber-concrete composite beams strengthened with fiberglass reinforced polymer. Composite Structures, v. 128, p. 145 - 154, 2015.

NADIR, Y.; NAGARAJAN, P.; AMEEN, M.; ARIF M, M. Flexural stiffness and strength enhancement of horizontally glued laminated wood beams with GFRP and CFRP composite sheets. Construction and Building Materials, v. 112, p. 547 - 555, 2016.

QING, C.; JIAN, W.P. Experimental study on bending behavior of timber beams reinforced with CFRP/AFRP hybrid FRP sheets. Advanced Materials Research, v. 255-260, p. 728 - 732, 2011.

RAFTERY, G.M.; WHELAN, C. Low-grade glued laminated timber beams reinforced usign improved arrangements of bonded-in GFRP rods. Construction and Building Materials, v. 52, p. 209 - 220, 2014.

ROSA GARCÍA, P. DE LA.; ESCAMILLA, A.C.; GARCÍA, M.N.G. Bending reinforcement of timber beams with composite carbono fiber and basalt fiber materials. Composite: Part B. v. 55, p. 528 - 536, 2013.

TEREZO, R.F.; SZÜCS, C.A. Análise de desempenho de vigas em madeira laminada colada de parica (Schizolobium amazonicum Huber ex Ducke), Scientia Forestalis, v.38, n.87, p.471 - 480, 2010.

TEREZO, R.F.; SZÜCS, C.A.; VALLE, A.; SAMPAIO, C.A. DE P.; STÜPP, A. M. Propriedades da Madeira de parica em diferentes idades para uso estrutural. Revista Ciência da Madeira, v. 6, n.3, p. 244 - 253, 2015. 